\title{
EKSISTENSI KEPONGOR DI BALI REFLEKSI TERHADAP AJARAN KARMAPHALA
}

\section{Nyoman Suharko; I Gede Suwantana; Ni Luh Gede Wariati}

Program Studi Filsafat Hindu, Fakultas Brahma Widya, Universitas Hindu Negeri I Gusti Bagus Sugriwa Denpasar Email: suharko04@gmail.com

Diterima tanggal 1 Januari 2021, diseleksi tanggal 12 Januari 2021, dan disetujui tanggal 2 Februari 2021

\begin{abstract}
Kepongor for the Hindu community in Bali is a belief (belief) based on a tradition and ancestral culture. Where the kepongor culture is a form of teaching about human behavior (deeds), ethics and morality which is applied from generation to generation through a curse, it is possible that all descendants are always aware of (remember) the ancestors. Religion is taught and socialized to humans based on the text of the Veda scriptures, lontar, and Bisama (warning) from generation to generation. This has served to provide a belief about how diversity and culture are carried out by humans based on the Five Sradha and Tri Hindu religious frameworks, tattwa, morals and events. On the basis of sradha and bahakti, things that are beyond human reason and logic that are abstract in nature which cause sorrow, pain, etc. can be avoided. Through the description above, the problems discussed in this study include: 1) the form of kepongor experienced by Balinese, 2) Balinese people can learn and overcome kepongor, 3) the implementation of karmaphala teachings on the incidence of kepongor
\end{abstract}

Keywords: Existence, Kepongor, Karmaphala

\begin{abstract}
ABSTRAK
Kepongor bagi masyarakat Hindu di Bali merupakan suatu keyakinan (kepercayaan) yang berlandaskan sebuah tradisi dan budaya leluhur. Dimana budaya kepongor adalah bentuk ajaran tentang prilaku (perbuatan), etika dan moralitas manusia yang diterapkan secara turun-temurun melalui sebuah kutukan, bisama agar semua keturunan selalu eling (ingat) trehadap leluhur. Agama yang diajarkan dan disosialisasikan terhadap manusia berdasarkan teks Kitab suci Veda, lontar, dan Bisama (peringatan) secara turun-temurun. Hal ini telah berfungsi memberikan suatu keyakinan tentang bagaimana keberagamaan dan budaya itu dilaksanakan manusia yang berlandaskan Panca sradha dan Tri kerangka agama Hindu tattwa, susila dan acara. Dengan dasar sradha dan bahakti, hal yang di luar nalar dan logika manusia yang bersifat niskala yang mengakibatkan kedukaan, kesakitan, dan lain sebagainya dapat dihindari. Melalui uraian tersebut di atas,
\end{abstract}


maka masalah yang dibahas dalam penelitian ini antara lain: 1) bentuk kepongor yang dialami orang Bali, 2) orang Bali bisa kepongor dan mengatasi kepongor, 3) implementasi ajaran karmaphala terhadap kejadian kepongor

Kata Kunci: Eksistensi, Kepongor, Karmaphala

\section{PENDAHULUAN}

Bali sarat dengan berbagai aktivitas religi yang mengekspresikan rasa ketuhanan, Semua aktivitas tersebut terbingkai dalam sebuah sistem religi, yaitu sistem religi Hindu. Hal ini dapat dibuktikan pada masa agama Hindu masuk kewilayah Nusantara. Sebelum masuknya agama Hindu masyarakat Nusantara menganut kepercayaan animisme dan dinamisme, sejak masuknya agama Hindu ke Nusantara sistem pemujaan terhadap roh leluhur masih dapat dilihat sampai sekarang secara turun-temurun.

Disetiap rumah orang Bali Hindu berdiri bangunan suci yang disebut dengan sanggah atau merajan sebagai tempat pemujaan Ida Sang Hyang Widhi Wasa dan pemujaan leluhur. Dharma (kewajiban) ini tercakup dan merupakan keharusan paratisentana (keturunan) yang disebut dengan Tri Rnam kata yang memiliki arti tiga hutang besar yang harus dibayar oleh manusia, atas pengorbanan, pengabdian serta kecintaan dan jasa yang luar biasa yang dilimpahkan kepada manusia (Pradnya, 2019: 108). Punarbawa bertujuan menghapus segala wasana dengan melaksanakan penebusan Tri rna. Ketiga hutang itu yang mencakup (1) hutang terhadap Ida Sang Hyang Widi Wasa, (2) hutang terhadap leluhur (Ibu Bapak) (3) hutang terhadap para Rsi (Rsi rnam). Menyembah Betara-betari (leluhur) merupakan suatu kewajiban karena para leluhur melahirkan, memelihara, dan mendidik generasi berikutnya. Atas dasar jasa-jasa tersebut maka leluhur patut disembah (Supatra 2007: 15)

Ida Sang Hyang Widhi Wasa menciptakan manusia dan makhluk lainnya melalui media-Nya, yakni leluhur dan Ibu-Bapak yang dalam Hindu disebut Pitara. Begitu juga Ida Sang Hyang Widhi Wasa memelihara manusia melalui media-Nya yakani Ibu-Bapak dengan penuh kasih sayang. Oleh karena itu manusia berhutang budi dan jasa yang besar terhadap leluhur terutama Ibu-Bapak yang harus dibayar oleh pratisantana (keturunan) dengan persembahan suci (korban suci) yang disebut Pitra Renam (Pitra yajna).

Salah satu penyebab kedukaan, kesakitan yang terjadi pada seseorang yang tidak dapat diketahui secara sekala (alam nyata) dan niskala (alam gaib), merupakan ketidak tahuan seseorang atas ego ke-akuan yang menganggap dirinya paling hebat, pintar, cantik dan tampan. Sehingga lupa terhadap norma-norma leluhur, hal ini merupakan suatu penyebab kepongor yang berkepanjanagan yang bersumber dari para leluhur yang memberikan teguran melalui pesan niskala. Siklus Kepongor yang dialami sebagian masyarakat hindu di Bali tentunya ada konflik di dalam diri maupun lingkungan, adanya kecemasan, rasa bersalah, rasa takut, dan rasa berhutang yang berpengaruh terhadap rasa kejiwaan keyakinan terhadap Tuhan dan leluhur yang telah memberikan suatu teguran melalui pesan niskala. Oleh karenanya diperlukan suatu media (ritual) secara niskala sesuai petunjuk seorang Sulinggih (pandita orang suci) dan jro dasaran (dukun).

Eksistensi kepongor di Bali yang dialami sebagian masyarakat Hindu dilihat dari kacamata karmaphala merupakan suatu gerak (kerja), penyimpangan prilaku yang menghasilkan baik dan tidak baik pada kehidupan seseorang yang melakukan 
perbuatan tersebut. Karma ini sesungguhnya masih bertahan akibat sesuatu dan terdiri dari perbuatan-perbuatan terdahulu sebagai akibat yang telah dilaksanakan. Dan menjadi suatu refleksi (cerminan) karma pada dirinya atau pada kehidupan baru yang kini dijalani. Hal inilah yang menjadi kajian dari artikel ini, tentang penyebab dan faktor apa yang mempengaruhi masyarakat Hindu Bali berkeyakinan terhadap kepongor begitu kuat, dan bagaimana keyakinan tentang ajaran Karmaphala dapat menjadi refleksi atas semua kejadian yang dialami manusia.

\section{PEMBAHASAN}

Dalam Kamus Bahasa Bali istilah Kepongor berasal dari bahasa Bali yang berasal dari akar kata "Pongor" atau"Mamongor" (memurkai) menjadi Kapongor (dimurkai) jadi kata Kapongor dapat diartikan suatu keyakinan setiap kesalahan, khilapan di murkai (Gautama, 2009:108) Katalog Dalam Terbitan (KDT). Dari suatu keyakinan yang berdasarkan keyakinan religius yang kuat, istilah kepongor merupakan suatu kata peringatan (teguran) yang sering didengar dari orang tua, Pemangku, dan Jro dasaran (balian). Sejarah kepongor di Bali sudah ada sejak dahulu berdasarkan cerita-cerita mitologi, dan dapat diketahui berdasarkan petunjuk dari seorang Sulinggih (orang suci) dan balian (dukun). Yang dimulai dari peristiwa sakit yang bernuansa gaib yang diluar kemampuan akal sehat manusia (niskala). Adapun cerita mitologi berdasarkan sumber lontar di Bali adalah sebagai berikut.

Lontar Purwa Bhumi Kemulan (dalam Soebandi: 2008: 26) disebutkan sebagai berikut: yan tan semangkana tan tugtug pali-pali sang Dewapitara manaken sira gawang tan molih ungguhan, tan hana pasenetanya. Terjemahannya: bila belum dilaksanakan demikian (belum dibuatkan tempat suci), belumlah selesai upacara dewapitara (leluhur) tidak mendapat suguhan dan tidak ada tempat tinggalnya. Disini maksudnya apabila tidak dilakukan upacara ngunggahang (ditempat suci) dewapitara (leluhur), maka upacara dewapitara belum selesai, dengan kutukan bahwa keturunan yang hanya tahu merasakan enaknya rasa makanan dan minum untuk diri sendiri, tanpa berbhakti kepada leluhur, maka sang dewapitara (leluhur) bisa menimbulkan kesengsaraan bagi keturunan dan sanak keluarganya.

Sebagian masyarakat menunjukkan bahwa banyak orang mengalami sakit yang tak kunjung sembuh sudah berobat kedokter dan alternatif lainya justru penyakitnya tak pernah terdiagnosa. Dan setelah bertanya kepada seorang Balian (dukun) ternyata penyakit yang dialaminya disebabkan oleh ganguan niskala (gaib). Hal senada dengan Tumanggor (dalam Pradnya 2014: 81), bahwa kepercayaan kepada yang gaib sebagai penyebab dan penyembuh penyakit yang banyak terjadi pada masyarakat itu. Menunjukan bahwa memang ada hubungan antara keyakinan agama dan penyakit hingga penyembuhannya.

Hal senada juga dijelaskan bapak I Made Surada yang dalam penjelassannya bahwa kepongor (kesisipan) merupakan suatu keselahan yang pernah dilakukan terdahulu dan dirasakan sekarang ini, dalam peradaban di Bali mengenal istilah kesisipan (kepongor). Kesisipan (kepongor) berasal dari leluhurnya, kawitannya misalnya seseorang tidak tahu kawitannya, sehingga seseorang mengalami tidak harmonis dalam keluarga contohnya, sering cekcok sakit dan lain sebagainya. Sehingga kadang sakit sudah diobati seorang dokter sepesialis sekalipun sakit tidak sembuh, sehingga begitu ada yang memberitau oleh orang pintar (balian) barulah 
mengetahui bahwa seseorang mengalami kesisipan. Lalu kesisipan (kepongor) merupakan bentuk kemarahan Tuhan tentunya tidak ada kaitannya, semua merupakan bentuk dari kesalahan diri manusia itu sendiri

Sesungguhnya kepongor bentuk penyimpanngan terhadap leluhur yang disebabkan atas kesalahan, kehilafan terhadap manusia yang melanggar sistem aturan agama (bhisama). Kepongor bisa juga disebabkan kekuatan energi alam Semesta ketika manusia menyalahi dan merusak alam. Hal ini dapat menyebabkan kerugian pada manusia itu sendiri seperti tanah longsor ketika pembalakan hutan, banjir bandang dan kekeringan. Inilah wujud kepongor yang disebabkan dari kekuatan energy alam semesta atas kesalahan yang dibuat manusia itu sendiri. Bentuk penyimpangan terhadap leluhur dapat diamati pada gambar berikut:

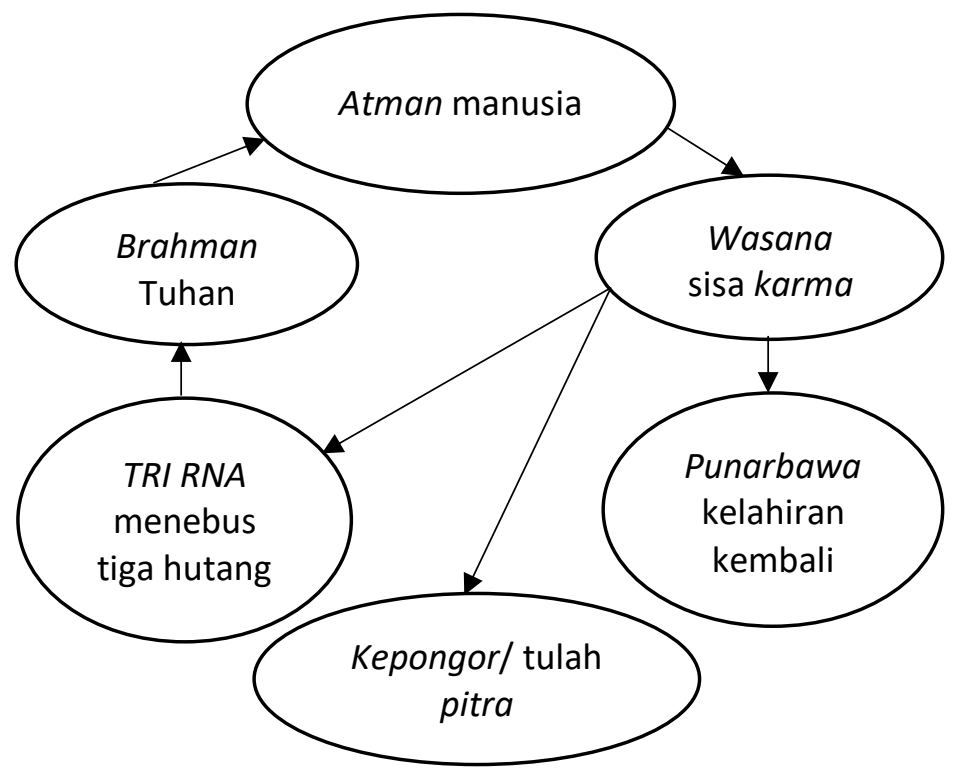

Gambar 2.1

Siklus Reinkarnasi dan terjadinya kepongor

Merujuk pada gambar 4.2.1 tersebut dapat dikemukakan bahwa manusia adalah Ilahi, sifat sejatinya adalah atman, tak terbatas, abadi, suci, selalu bebas, penuh kebahagiaan dan identik dengan Brahman. Manusia bukanlah pendosa, manusia membuat kesalahan dan menderita karena kebodohannya (Kamajaya dalam Pradnya, 2019:108). Kepongor terjadi apabila, umat Hindu dalam reinkarnasinya tidak melunasi hutang terhadap Tri Rna, yaitu para dewa, leluhur dan para guru suci, penyimpangan agama ini dikutuk karena berani dengan leluhur (tulah pitra). Eksistensi orang kepongor di Bali disebabkan perasaan sadar dan takut umat Hindu, ketika para leluhur memberikan ujian dan cobaan berupa sakit misterius yang tidak mampu disembuhkan siapapun.

Adapun dampak yang diakibatkan dari kepongor adalah dapat dirasakan secara langsung maupun tidak langsung, dan wujud kepongor dalam penelitian ini tidak hanya berbicara wujud kepongor secara personal (individu), tetapi juga menjelaskan tentang wujud kepongor yang bersifat kolektif (keseluruhan). Kepongor yang bersifat kolektif (keseluruhan) berdasarkan sumber informan menyebutkan, berbicara tentang keyakinan ( sradha) setiap yang dialami oleh orang siapapun dan seseorang itu terjebak di sana hal itu merupakan kaitan proses 
persamaan karma bisa juga disebut dengan pertemuan karma. Di dalam upanisad disebutkan apapun yang kamu lakukan tidak kamu sendiri yang menikmatinya, contohnya seseorang berkendara motor lalu ada pengendara lain yang menabrak dari belakang hal ini tentu yang menabrak yang salah, tetapi secara akal sehat yang menabrak juga tidak ingin menabrak orang lain, hal inilah yang ada hubungannya dengan persamaan karma yang berdasarkan sradha yang memunculkan bhakti (wawancara bapak I Made Surada, 27 januari 2020).

Kepongor merupakan penyimpangan yang dilakukan seseorang dan dapat berdampak kepada orang lain, hal ini merupakan proses kaitan karmaphala yang belum habis dan harus menjalanni pada kehidupan saat ini. Persamaan karmaphala dalam keyakinan agama Hindu merupakan hal yang tidak bisa dihindari dalam proses reinkarnasi setiap orang.

\subsection{Wujud kepongor}

Wujud dari kepongor yang dialamai seseorang yang diperoleh dari beberapa sumber yakni dari mereka yang pernah langsung mengalami kasus kepongor terutama kepongoran terhadap leluhur. Yang berupa ketidak nyamanan tersebut diyakini sebagai datangnya dari kekuatan leluhur dan Ida Bhatara diantaranya sebagai berikut:

\section{a. Kehidupan Keluarga Tidak Harmonis}

Kehidupan awal berkeluarga adalah momentum penting untuk meneguhkan kehidupan, dan keyakinan keagamaan seseorang. Komitmen membangun rumah tangga baru oleh pasangan suami-istri yang disahkan oleh ritual keagamaan serta pencatatan secara hukum, menjadikan pelaku perkawinan tidak saja memproklamirkan identitas barunya sebagai pasangan suami-istri, tetapi juga menegaskan identitas keagamaan yang dianut. Dalam berkeluarga, pasangan suami-istri yang berasal dari agama yang berbeda hendaknya bersama-sama memahami tentang ajaran agama yang dianutnya, untuk menghindari ketidak harmonisan dalam keluarga.

\section{b. Sakit-sakitan}

Setiap orang pasti tidak menginginkan sakit dalam kehidupan ini, pada saat sesorang mengalami sakit tentunya berbagaicara harus ditempuh demi mendapatkan kesembuhan. Salah satu nya adalah daiwabala prawarta penyakit ini disebabkan oleh gangguan niskala (tidak tampak) dan biasanya tiba-tiba sakit dan tidak diketahui penyebabnya.

\section{c. Perekonomian Tidak Menentu}

Perekonomian dalam kehidupan berkeluarga merupakan hal yang paling mendasar, ketika perekonomian tidak dapat memenuhi kebutuhan dalam hidup apa yang terjadi, tentunya pasti membuat seseorang melakukan tindakan-tindakan yang menyimpang dari norma-norma kehidupan.

\section{d. Tidak Betah Tinggal di Rumah}

Ketika keadaan dalam suatu lingkungan rumah tangga, keharmonisan, perekonomian, ketentraman, kedamaian dan kenyamanan sudah tidak adalagi dalam lingkungan. Tentu hal inilah menjadi penyebab baik anak, istri dan bahkan keseluruhan anggota keluarga tidak betah, bahkan meninggalkan lingkungannya. Keadaan lingungan rumah sangat berpengaruh terhadap penghuninya. 


\section{e. Pikiran Kalut}

Pikiran merupakan penentu arah, kemana dan apa yang harus seseorang lakukan dan seseorang harus bisa memilah-milah mana yang baik dan mana yang tidak baik. Dalam keyakinan agama Hindu ajaran tentang tata susila merupakan bersumber dari Tri Kaya Parisudha, yaitu pikiran, perkataan dan perbuatan yang baik Tri Kaya Parisudha merupakan landasan etik yang tertingi dari ajaran Tata Susila Hindu.

\subsection{Penyebab Kepongor dan Cara Mengatasi Kepongor}

Beberapa kutukan yang tercantum dalam berbagai teks sastra mencerminkan kentalnya kepercayaan suatu kutukan, kepongoran, tulah pitra, tilas kawitan dan lain-lai dalam masyarakat Hindu di Bali. Hal tersebut tidaklah terlepas dari bentuk perbuatan atas kesalahan, kehilafan manusia itu sendiri dalam kehidupannya saat ini. Dimana pada tingkat zaman milenial yang serba canggih, tak heran jika manusia sudah melampaui batasan-batasan dan norma-norma agama, budaya, dan tradisi yang sejak dahulu memang sudah ada yang diwariskan leluhur orang Bali.

Bagi masyarakat Hindu Bali menganggap bahwa segala sesuatu ini pastilah diciptakan oleh kekuatan Tuhan beserta manifestasi-Nya dan suatu saat nanti pasti pula dilenyapkan oleh kekuatan Beliau. Hal ini juga dituangkan pada kitab (Bhuwanakosa III, 80):

Sakweh ning jagat kabeh, mijil sakeng Bhatara Siwa ika, linaa ring Bhatara Siwa

Terjemahan:

Seluruh alam ini muncul dari Bhatara Siwa, lenyap kembali kepada Bhatara Siwa (Gautama, 2009: 29)

Dengan adanya kejadian kepongor terhadap seseorang dapat merubah etika masyarakat untuk berpikir, berbuat dan berkata yang baik dan benar. Dimana kepongor merupakan pemahaman tentang suatu perbuatan dan etika yang menyimpang yang diajarkan sangat sederhana oleh leluhur orang Bali. Adapun penyebab kepongor berdasarkan sumber dari seorang Sulinggih, Pemangku, dan orang yang mengalami langsung adalah sebagai berikut:

\section{Kepongor karena leluhur}

Kepongor yang disebabkan oleh leluhur merupakan hal yang menarik karena sering terdengar dari beberapa orang yang sudah mengalami, yang diproleh berdasarkan ucapan balain (dukun). Kepongor, kesisipan, keduken. Inilah yang sering diucapkan jro balian (dukun) Hal ini menjadi pertanyan dalam diri sendiri, untuk menjawab rasa keraguan perlu adanya pengetahuan tentang siapa leluhur itu.

Sesungguhnya ibu dan bapak merupakan perwujudan Tuhan itu sendiri dalam bentuk nyata, umat Hindu menyebutnya punarbawa atau samsara dipercaya kakek dan nenek yang telah meninggal kembali lahir menjadi cucu (keturunan) berikutnya. Kepercayaan ini masih kental diwarisi bahkan sangat dipercaya oleh masyarakat Hindu di Bali, permasalahan dapat terjadi ketika keturunannya tidak lagi memperhatikan leluhurnya, seperti contoh pindah agama, tidak pernah tangkil (datang) sembah sujud di Pura Kawitan dan lain sebagainya.

\section{Kepongor makhluk halus}


Menurut Subagia gangguan yang bersifat niskala tidak saja berupa gangguan dari leluhur, dan sejenisnya, tetapi gangguan yang datang dari adanya sebuah emik, bahwa adanya makhluk astral jadi-jadian yang sering disebut leak. Masyarakat Hindu di Bali sangat meyakini bahwa gangguan niskala yang muncul bagi warga yang mengalami adalah black magis (leak).

Leak yang dimaksud adalah leak pamoroan, yaitu makhluk-makhluk gaib yang dikirim seseorang dengan sengaja untuk menyakiti oarang lain (Subagia dalam Pradnya, 2019: 120).

Kemampuan tersebut dalam ilmu patologi social disebut teori demonologis, yaitu berasal dari kata demon berarti roh jahat, iblis, setan. Teori deomonologis menyebutkan sebab-musabab kekalutan mental, yaitu unsur-unsur mistik gaib dan setan-setan atau roh jahat atau hasil dari perbuatan dukun-dukun jahat (Kartini dalam Pradnya, 2019: 121).

Sesuai teori demonologis, maka seseorang kacau, kalut dan mudah di ganggu black magic (leak pamoroan) karna umat Hindu telah melupakan bahkan tidak mau tahu terhadap penghormatan kapada Ida Sang Hyang Widhi Wasa maupun leluhur (pitra). Hal tersebutlah yang menyebabkan para dewa tidak menjelma dalam kehidupan umat yang telah melupakannya.

\section{Kepongor karena Tuhan}

Semua ciptaan yang ada di bumi merupakan hasil karya dari Ida Sang Hyang Widhi wasa, beliau maha kuasa, maha pengasih dan segala-galanya beliau berada disetiap makhluk (atman). Mendekatkan diri kepada Tuhan Yang Maha Esa merupakan hal yang wajib untuk dilakukan guna mewujudkan kesejahteraan dan kebahagiaan yang sejati. Tuhan Yang Maha Esa digambarkan sebagai Mahapurusa yang maha agung, sangat dihormati, disayangi, sangat didambakan kasih-Nya, di gambarkan sebagai ibu, bapak, kakak, adik, saudara, sahabat, orang tua yang sangat dicintai, tamu dan lain sebagainya (Titib, 1996: 204).

Berdasarkan hal tersebut di atas dapat disimpulkan bahwa, tanpa adanya Tuhan Yang Maha Esa atas segala kemahakuasaan Nya tidaklah mungkin ada tempat berpijak bagi semua makhluk. Bentuk-bentuk penghormatan kepada Tuhan yang dilakukan seluruh umat Hindu di Bali, dilaksanakan atas dasar konsep ajaran Hindu yaitu Tri Hita Karana. Konsep ajaran Tri Hita Karana bersal dari kata Tri berarti tiga. Hita berarti kebahagian, dan karana berarti penyebab. Dengan demikian Tri Hita Karana adalah tiga penyebab kebahagian.

\section{Kepongor karena alam}

Alam semesta (bumi) merupakan tempat dimana semua makhluk hidup tinggal didalamnya, dalam susastra agama Hindu alam semesta wujud dari Tuhan itu- sendiri. Keberadaan alam semesta yang dilengkapi dengan berbagai hukum-hukumnya menjadi objek studi bagi manusia, padahal pada sisi lain manusia juga merupakan bagian kecil dari alam semesta. Alam semesta membuat takjub manusia untuk melihatnya baik disaat siang maupun malam.

\subsection{Cara Mengatasi kepongor}

Kultur dan religius dalam masyarakat Bali, saat menjalankan tugas dalam swadharmanya selalu bersandar pada etika dan moral masing-masing sehingga 
dapat menjalankan peran dengan baik. Serta dipertanggungjawabkan secara sekala maupun niskala, peran tersebut diyakini dan nyata dalam kehidupan sehari-hari. Peran penting pemangku dan balian disebabkan atas sumbangsihnya dalam memberikan ketentraman batin kepada masyarakat yang memohon bantuannya di bidang ritual maupun supernatural. Persaan nyaman dalam batin yang dihubungkan dengan kekuasaan Tuhan, menjadikan agama semangkin kokoh dalam keyakinan pemeluknya. Adapun cara mengatasi kepongor dalam hal ini dapat melakukan hal-hal sebagai berikut:

\section{Mebayuh atau penebusan}

Ketika dalam menjalankan roda kehidupan, tidak jarang seseorang mengalami hal baik maupun tidak baik, dan berusaha untuk mecari penyebab dibalik semua itu. Baik secara sekala maupun secara niskala, ketika secara sekala sudah ditempuh namun tidak menemui titik terang, barulah seseorang menempuh jalan niskala untuk mengetahui apa sesengguhnya dibalik semua itu. Seperti melakukan melukat (pembersihan diri), bayuh oton (menebus hari kelahiran), neduhin (permohonan maaf).

\section{Bhakti kepada Tuhan (Ida Sang Hyang Widi Wasa)}

Rasa syukur dan bhakti atas karunia-Nya merupakan hal yang patut, bila Manusia mampu untuk senantiasa menumbuhkan sikap bhakti, menyucikan pribadi melalui berbagai sadhana (latihan rohani). Seperti vrata (pengendalian diri), upavasa (puasa), Tuhan Yang Maha Esa niscaya menganugrahkan karunia-Nya. Sebaliknya mereka yang tidak mengerti, dan pada dirinya tidak dilingkupi rasa bhakti, tidak ikhlas menghadapi persoalan hidup, kadang putus asa, hanyut oleh emosi, ambisi dan nafsu. Emosi (krodha), ambisi (lobha), nafsu (kama) dalam Bhagavadgita disebut tiga pintu gerbang yang mengantarkan atman (roh) menuju tiga pintu gerbang neraka, kehancuran.

Tri vidham narakasyedam, Dvarum nasanam dimanah

Kamah krodhas tatha, Lobhas tasmad etat trayam tyajet. (Bhg. XV1. 21)

Dalam kutipan sloka Bhagavadgita diatas ini merupakan jalan (pintu gerbang) menuju neraka, jalan menuju jurang kehancuran sang diri, yaitu nafsu, (Kama) amarah, (krodha) dan ambisi (lobha) setiap orang harus meninggalkan ketiga sifat ini. Untuk dapat menghindar diri dari berbagai cobaan dan ujian hidup seseorang harus berpegang, memahami, mempedomani dan mengamalkan ajaran agama dengan baik.

\section{Melestarikan alam}

Konsep melestarikan alam merupakan bentuk suatu kesadaran dalam diri manusia masing-masing, jika tidak manusia itu sendiri siapa lagi yang melestarikan alam ini. Dalam agama Hindu tujuan manusia diciptakan merupakan untuk menjaga dan melestarikan alam ini. Setiap manusia sesungguhnya mempunyai kewajiban luhur, suci, dan universal untuk menunjukan mana yang benar dan mana yang buruk, serta memeilih yang baik saja. Itulah sesungguhnya peran manusia sehingga dilahirkan ke dunia.

\section{Mawas diri}

Suatu keunggulan yang tidak dimiliki oleh mahkluk lain adalah viveka (kemampuan untuk membedakan mana yang baik dan mana yang buruk), viveka sesungguhnya tidak lain adalah pikiran, pada tingkatan lebih tinggi dimana pikiran mampu melakukan seleksi terhadap sesuatu hal mana yang 
memiliki nilai yang kekal. Dalam ajaran agama Hindu pengendalian diri (mawas diri) diistilahkan dalam konsep Tri Kaya Parisudha yaitu; berpikir benar, berkata benar dan berbuat yang benar.

a. Manacika Parisudha adalah pikiran yang baik, caraberpikir benar, diantaranya adalah, pikiran yang tidak memikirkan hal-hal yang negatip. Tidak menginginkan sesuatu yang bukan menjadi haknya.

b. Wacika Parisudha adalah berkata yang benar, baik, ada empat (4) banyaknya yang timbul dari kata-kata yang patut dikendalikan, bahkan diusahakan untuk tidak diucapkan. Keempat hal tersebut yaitu; (1) Perkataan yang kasar, keras, membentak (2) Perekataan yang jahat yang menyakitkan hati orang lain, (3) Perkataan yang memfitnah, (4) Perkataan bohong.

c. Kayika Parisudha adalah perbuatan yang dilakukan anggota badan, seperti tangan, kaki, mata, dan lain-lain yang sifatnya adalah fisik.

\section{Pasrah pada hukum karmaphala}

Pada hakikatnya semua proses kehidupan dialam semesta ini merupakan hasil dari perbuatan, tindakan (kerja), adalah setiap kerja dan gerak dapat berpengaruh terhadap hasil dari kerja itu sendiri. Karma yang menentukan apa yang patut dilakukan dan yang patut di pahami. Manusia bertanggung jawab untuk apa manusia itu ada, apa-pun yang seseorang hendaki, apa diri ini dan apa-pun yang dialami pada kehidupan ini merupakan hasil dari perbuatan sekarang. Perbuatan merupakan warisan pahala baik dan buruk, yang diperolehnya dari perbuatan terdahulu, selama seseorang menjalani kehidupan didalam raga kasar ini, orang tersebut tidak bisa menghindari perbuatan, tanpa perbuatan hidup tidak bisa dipertahankan. Pasrah terhadap hukum karmaphala merupakan suatu cerminan, ketidak terikatan manusia terhadap perbuatan, karena hakikatnya semua di kuasai purwakarma (perbuatan terdahulu).

\subsection{Kepongor Dalam Konteks Hukum Karmaphala}

Dua suku kata yang berbeda antara kepongor dan karmaphala namun memiliki makna yang-sama, adalah hakikat tentang perbuatan manusia. Kepongor (dimurkai) diakibatkan karena ketidaktahuan (ego, kehilafan, kesalahan). Sedangkan karmaphala terdiri dari dua kata yaitu karma dan pahala, karma maknanya perbuatan sementara pahala artinya buah, oleh karena itu karmaphala berarti buah dari perbuatan, baik yang telah maupun yang hendak dilakukan.

Kepongor dalam konteks karmaphala berdasarkan perspektif masyarakat dalam hal ini menurut bapak I Made Surada menjelaskan, agama Hindu di Bali mengenal adanya Tri kerangka agama Hindu, tattwa, susila dan acara. Jadi secara tattwa ketika leleuhur ingin menolong keturunannya namun keturunan tidak memeiliki tempat pemujaan terhadap leleuhur, maka hubungan antara leluhur tidak tercapai secara vertikal dalam bentuk etikanya, sedangkan dalam bentuk upacara melakukan pemujaan dan persembahan. Kaitan kepongor terhadap karmaphala memiliki hubungan yang tidak dapat dipisahkan, dalam hal ini merupakan suatu landasan yang menyebabkan kepongor, dalam penyimpangan karma yang dilakukan adalah tidak vertikalisasi hubungan antara keturunan dan leluhurnya (wawancara I Made Surada, 27 Januari 2020). 
Jadi kepongor maupun dalam bentuk hukum karmaphala sama-sekali bukan nasib sebagai takdir Tuhan (yang berarti semuanya ditentukan oleh Tuhan), melainkan manusia sendiri yang merancang nasibnya sendiri. Atas apa tindakan itu pikiran, perkataan, perbuatan manusia itu sendiri yang dalam agama Hindu disebut dengan Tri kaya parisudha (tiga jenis perbuatan), oleh karena ada suatu aksi, maka ada suatu reaksi yang di timbulkan. Contoh kalau seseorang bersikap sombong, maka kelak yang datang pada orang itu adalah kebencian, kalau seseorang penuh kebaikan maka yang datang kelak adalah simpati dan pertolongan.

Menyikapi hal tersebut di atas karmaphala merupakan hasil dari keyakinan manusia terhadap agama, dan ketika manusia merealisasikan apa yang telah diketahuinya maka manusia menuangkan dalam praktek adat dan budaya. Hal ini merupakan suatu bentuk-cara manusia untuk memanfaatkan bumi dan melindungi dirinya terhadap kekuatan-kekuatan alam. Dalam hal ini kepongor merupakan konteks pemahaman tentang karmaphala yang memang sejak dahulu sudah ada sebelum agama itu ada, yang penerapannya selalu terangkum dalam tattwa kebudayaan, agar lebih mudah untuk dipahami dan dilaksanakan.

\subsection{Implementasi Karmaphala Terhadap Kepongor}

Karma berasal dari kata "kr" yang diambil dari kata Sansekerta yang artinya bergerak. Yakni segala gerak atau aktivitas yang dilakukan, baik itu perbuatan disengaja dan tidak disengaja. Perbuatan itu baik dan buruk, benar dan salah. Karma phala adalah sebab akibat, maka segala sebab pasti membawa akibat. Demikian juga sebab dari suatu gerak atau perbuatan menimbulkan akibat. Karma juga adalah perbuatan manusia ketika hidup didunia.

Bila dilihat dari uraian pengertian karmaphala diatas, maka karmaphala adalah sebab akibat dari setiap perbuatan. Segala sebab membawa akibat, segala sebab yang berupa perbuatan membawa hasil perbuatan. Adanya hukum karmaphala disebabkan oleh perbuatan itu sendiri. Pada dasarnya sesuai dengan siklus rwabhineda (dua sisi yang berbeda), perbuatan itu terjadi dari dua sisi yang berbeda, yaitu perbuatan baik dan perbuatan buruk. Siklus baik dan buruk selalu saling berhubungan satu-sama lain dan tidak dapat dipisahkan. Demikianlah perilaku manusia selama hidupnya berada pada dua jalan yang berbeda itu, sehingga dengan kesadaran dia harus dapat menggunakan kemampuan yang ada di dalam dirinya, yaitu kemampuan berfikir, kemampuan berkata dan kemampuan untuk berbuat. Hukum karmaphala dapat menentukan seseorang itu hidup bahagia dan menderita lahir batin. Jadi setiap orang berbuat baik (Subhakarma), pasti menerima hasil dari perbuatan baiknya itu. Demikian pula sebaliknya, setiap yang berbuat buruk, maka keburukan itu sendiri tidak bisa terelakan dan pasti diterima. Hasil dari perbuatan itu tidak selalu langsung dapat dirasakan atau dinikmati. Dengan demikian karmaphala dapat digolongkan menjadi tiga macam sesuai dengan saat dan kesempatan dalam menerima hasilnya yaitu sancita karmaphala, prarabda karmaphala dan kriyamana karmaphala (Kurniawan, 2013: 50).

1) Sancita Karmaphala Adalah hasil perbuatan dalam kehidupan terdahulu yang belum habis dinikmati dan masih merupakan benih yang menentukan kehidupan kita yang sekarang. Maksudnya perbuatan baik yang dulu pernah kita lakukan tapi belum mendapat pahala, akhirnya dilahirkan kembali selama belum mencapai moksa. Untuk menerima pahala dan perbuatan baik itu terus menerus sampai mencapai moksa. 
2) Prarabda KarmaphalaAdalah hasil perbuatan pada kehidupan ini, yang buah karma-nya (karmaphala) dan karmaphala matang dan diterima di saat seakarang juga.

3) Kriyamana Karmaphala Adalah hasil perbuatan yang tidak sempat dinikmati pada saat berbuat, sehingga harus diterima pada kehidupan yang datang. Maksudnya perbuatan yang pernah dilakukan tapi belum sempat mendapat balasan atau pahala maka diterima pada kehidupan yang datang. Contohnya, seseorang melakukan perbuatan baik tapi pada kehidupan ini belum mendapat balasan. Maka kehidupan yang datang mendapatkan pahala kebahagiaan. Jadi adanya penderitaan dalam hidup ini walaupun seseorang selalu berbuat baik, hal itu disebabkan oleh karmanya (perbuatan) yang lalu (sancita karma) terutama yang buruk yang harus di nikmati hasilnya sekarang.

Dengan adanya tiga jenis karmaphala tersebut, implementasi karmaphala terhadap kepongor dapt menjadi pemahaman. Bahwa nasib yang di terima dalam kehidupan yang sekarang ditentukan oleh karma yang telah di lakukan dalam kehidupan yang terdahulu. Sehingga kalau sesorang di hari ini hidup banyak kesulitan, selalu bertemu hal yang tidak baik dan lain-lain tidak perlu protes kepada Tuhan, kepada kehidupan, kepada para dewa-dewi (Ida Betara). Sadarilah bahwa itu hanya buah dari apa-yang telah dilakukan di saat ini atau di masa lalu. Dan karma yang di lakukan dalam kehidupan yang sekarang menentukan nasib yang di terima dalam kehidupan yang datang.

Implementasi ajaran karmaphala dalam hal kepongor jika dikaji dari konsep ajaran karmaphala. Yaitu semua menyangkut tentang ajaran kesusilaan, etika, moral dan perbuatan manusia. Kepongor merupakan suatu istilah (pengucapan) tantang ajaran hukum karmaphala di Bali yang telah diwariskan oleh leluhur orang Bali sebelum paham agama Hindu masuk ke wilayah Nusantara, ajaran tentang perbuatan yang menyimpang yang dilakukan oleh manusia. Terutama penyimpangan (kesalahan) terhadap leluhur hal inilah yang menjadi penyebab kepongor (dimurkai) dan jika dikaitkan terhadap karmaphala tentu apa-yang diperbuat maka harus siap menerima hasilnya.

\section{SIMPULAN}

Bentuk kepongor yang dialami orang Bali, merupakan sebuah fenomena budaya tentang keyakinan adanya murka para Dewa-dewa, leluhur dan alam. Yang dimulai dari peristiwa sakit yang bernuansa gaib yang diluar kemampuan akal sehat manusia (niskala). Penyakit yang bernuansa niskala disebut Daiwala prawrta, yaitu penyakit akibat gangguan niskala, supranatural (tidak tampak).

Mengapa orang Bali bisa kepongor dan bagai manacara mengatasinya. Hal tersebut tidaklah terlepas dari bentuk perbuatan atas kesalahan, kehilafan manusia itu sendiri baik sadar maupun tidak sadar dalam kehidupannya saat ini. Manusia sudah melampaui batasan-batasan dan norma-norma Agama, Budaya, dan Tradisi yang sejak dahulu memang sudah ada yang diwariskan leluhur. Kepongor merupakan hasil dari perbuatan seseorang dan dapat diatasi melalui sujud bhakti terhadap Ida Bhatara (Tuhan), bhakti terhadap leluhur, melakukan guru piduka (permohonan maaf), ngakuagem (berjanji dalam arti harus ditepati), mebayuh oton (hari kelahiran), melestarikan alam sesuai konsep Tri hita karana dan selalu 
menjaga pikiran, perkataan dan perbuata dalam menjalani kehidupan sesuai dengan jalan dharma.

Implementasi ajaran karmaphala terhadap kejadian kepongor adalah dengan memahami pengertian dari karmaphala. Adanya hukum karmaphala disebabkan oleh perbuatan itu sendiri, pada dasarnya sesuai dengan siklus rwabhineda (dua sisi yang berbeda), perbuatan itu terjadi dari dua sisi yang berbeda, yaitu perbuatan baik dan perbuatan buruk. Berdasarkan hal itu, maka salah satu aspek implementasi (penerapan) karmaphala terhadap kepongor dalam kehidupan manusia adalah sebagai pancaran dari kemampuan dan daya pikirnya. Dengan demikian karmaphala dapat digolongkan menjadi tiga macam sesuai dengan saat dan kesempatan dalam menerima hasilnya yaitu: (1) Sancita Karmaphala (2) Prarabda Karmaphala (3) Kriyamana Karmaphala.

\section{DAFTAR PUSTAKA}

Gautama, Budha W. 2009. Kamus Bahasa Bali. Surabaya: Paramita.

Gautama, Budha Wayan. 2009 Tutur Bhuwana Kosa. Surabaya: Paramita

Kurniawan, I Nyoman. 2012. Perjalanan Sang Jiwa Dalam Kehidupan dan Kematian, Surabaya: Paramita.

Pradnya, I Made Adi Surya. 2019. Rekonversi Agama Kembali Ke Jalan Dharma. Denpasar: Pustaka Ekspresi.

Prabhupada, Swami. 2006. "Bhagavad Gita Menurut Aslinya”. Hanuman Sakti.

Supatra, I.N.K. 2007. Penuntun Dasar dan Praktis Sembahyang. Denpasar: CV. Kayumas Agung.

Soebandi, Ketut. 2008. Riwayat Merajan Di Bali. Denpasar: CV. Kayumas Agung.

Titib, I Made. 1996. Veda Sabda Suci: Pedoman Praktis Kehidupan. Surabaya: Paramita. 